\title{
The correlation empirical analysis of China Citic Bank stock $\beta$ coefficient and stock value
}

\author{
LanXiuWen Ren Fengfeng
}

Inner Mongolia University of Finance and Economics, Hohhot, Inner Mongolia, 010070

L3677433@sina.com

Keywords: $\beta$ coefficient; China Citic Bank; stock prices

\begin{abstract}
. $\beta$ coefficient, a kind of risk index, is used to measure individual stocks or whole price volatility of stock funds relative to the stock market. The greater its absolute value is, the greater its earnings change than the change range of broader market; The smaller the absolute value is, the smaller the earnings change than that of broader market. Based on the data of China Citic Bank (601998) between January 2008 and December 2008, this paper revealed China Citic Bank share prices' sensitivity of the overall stock market fluctuations through CAPM model and least squares regression.
\end{abstract}

\section{Introduction}

Since 1998, with the formation and development and the increasingly mature of China's securities market, CAPM theory is studied by more and more scholars. As can be seen from a lot of research, Chinese scholars have accumulated rich theoretical research results through their own efforts, especially $\beta$ coefficient's empirical research in China's stock market, which provides rich theoretical basis for the healthy development of China's securities market.

\section{Capm Theory and B coefficient}

In the early 1950s, H. Markowits put forward portfolio theory. He initiatively put forward variance measure portfolio risk, and provided the necessary conditions for CAPM theory and risk management theory. In the 1960s, American scholar William Sharpe (1964), John Lintner (1965), and Jan Mossin (1966) combined EMH and H. Markowits portfolio theory, and set up a investor behavior Model based on rational expectation in general equilibrium framework, which was named CAPM (Capital Asset Pricing Model). It is a mainstay of modern financial market price theory, and is widely applied in investment decision-making and corporate finance field. The mathematical form is expressed as:

$$
\mathrm{E}\left[\mathrm{R}_{\mathrm{i}}\right]=\mathrm{R}_{\mathrm{f}}+\mathrm{R}_{\mathrm{im}}\left(\mathrm{E}\left[\mathrm{R}_{\mathrm{m}}\right]-\mathrm{R}_{\mathrm{f}}\right) \quad \mathrm{R}_{\mathrm{im}}=\operatorname{Cov}\left[\mathrm{R}_{\mathrm{i}}+\mathrm{R}_{\mathrm{m}}\right] / \operatorname{Var}\left[\mathrm{R}_{\mathrm{m}}\right]
$$

In CAPM theory, $\beta$ coefficient is a key index to measure the relationship between securities (or portfolio) price changes and average stock price changes on the market. It reflects the impacts of average stock price changes on the market on the price change of one security (or portfolio), and is a risk assessment tool used to measure the volatility of a security or a portfolio relative to overall market. So the inspection of CAPM is actually to verify whether $\beta$ coefficient has the ability to fully explain the benefits.

The research and application of $\beta$ coefficient have been one of the hot spots in asset pricing and risk management theory and practice in capital market, which focuses on the stability of $\beta$ coefficient and its characteristics. Since Blume (1971) published the first paper on the stability of $\beta$ coefficient research, many scholars pay close attention to this problem. With the extension, breadth and depth of study, a large number of research results and papers produced. Early research mostly concentrated in the 20th century, 70-80s, and there are still a lot of research literature studies involving $\beta$ coefficient in 90s. From the research time or number, the importance of $\beta$ coefficient can be illustrated, and there are still some controversial issues showed during the study. 


\section{The Introduction of China Citic Bank}

China Citic Bank (601998. SH, 0998. HK) was founded in 1987, formerly known as China Citic Industrial Bank. It was one of the earliest established emerging commercial Banks in China's reform and opening, and the commercial bank earliest involved in the financial markets financing at home and abroad, and repeatedly got famous in China's modern financial history. Along with China's rapid economic development, China Citic Industrial Bank gradually grew in the tide of China's financial market reforms. In August 2005, it was officially changed its name as "China Citic Bank". In December 2006, China Citic Group in China and Citic International Financial Holdings Co., LTD. were shareholders, and formally established China Citic Bank Co., LTD. In the same year, it successfully introduced strategic investors, and established complementary strategic cooperative relations with Europe's leading BBVA (BBVA). On April 27, 2007, China Citic Bank listed successfully synchronized in Shanghai stock exchange with that of stock exchange of Hong Kong. In 2009, China Citic Bank successfully acquired China Citic International Financial Holdings co., LTD. (China Citic International) 70.32\% stake. After 20 years development, China Citic Bank has become one of the most abundant domestic capital strength commercial Banks, and is a national commercial bank with rapid growth and strong comprehensive competitiveness.

China Citic Bank’s business radiation covers nearly 130 countries and regions, 78 branches and 622 sub-branches throughout the country, which mainly distribute in the eastern coastal areas and economically developed cities in the Midwest. He has more than 33000 employees; including more than 26000 professionals provide high quality services to enterprise customers, company bank business, international business and financial capital markets business, comprehensive financial solutions such as investment banking, at the same time provide comprehensive financial products to individual customers such as personal finance, credit cards, consumer credit, private banking, abroad financial and others.

China Citic Bank has established independent, comprehensive, vertical, and professional risk management system, pursues risk-filtering benefits, improves technical ability of quantitative risk under Basel and risk management requirements, in order to strengthen the management of capital constraint, and constantly enhances the level of asset management and internal management. In recent years, China Citic Bank credit assets defective rate is well below the average level of listed Banks, and asset quality is improved significantly. With rapid development of business, good management ability, outstanding financial performance, prudent risk control, China Citic Bank in recent years has gained widespread industry recognition, and is favored by domestic and foreign authorities. Britain's Financial Times published "World's top 500 enterprises in 2010”, China Citic Bank was ranked 185th. In 20101000 Banks of Banker magazine in UK, China Citic Bank’s tier 1 capital and total assets ranked the 67th and 72th respectively in the world rankings. In UK Brand Consultancy Company's Brand Finance2010 evaluation, China Citic Bank Brand was one of the top 500 most valuable brands in the world, ranked 480th, and the Brand value is of $\$ 2.342$ billion. In China Financial times and Chinese Academy of Social Sciences 2008-2010 Chinese financial institutions golden award "gold dragon" selection activities, China Citic Bank was named" Best Joint-stock Commercial Bank" title in two consecutive years.

\section{Correlation Empirical Analysis of China Citic Bank $\beta$ coefficient and Stock Value}

This article selected China Citic Bank shares monthly closing price during 2008-01-04 to 2012-09-28 to calculate on yields, and collected and calculated the corresponding month return of Shanghai composite index (000001). There were 60 data value analysis (data in the table), and regression analysis, heteroscedasticity and autocorrelation and unit root test were conducted by using Eviews,.

Model set 


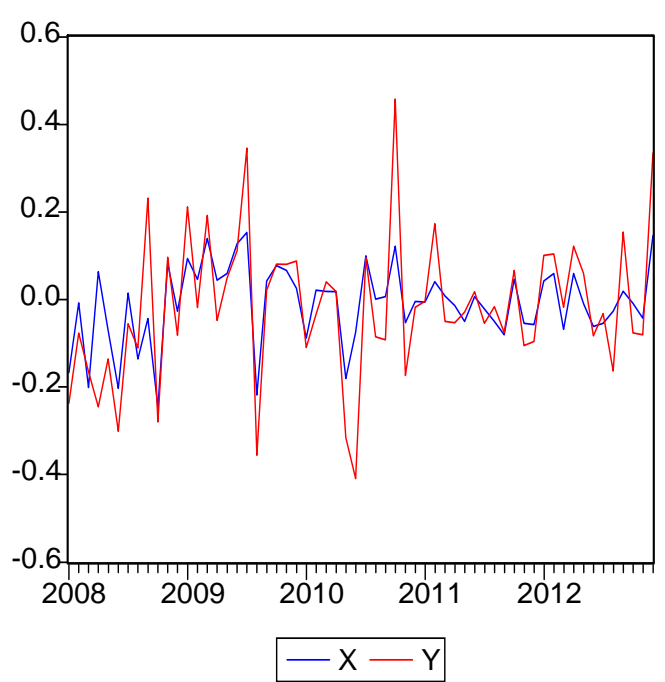

Figure 1 Line chart

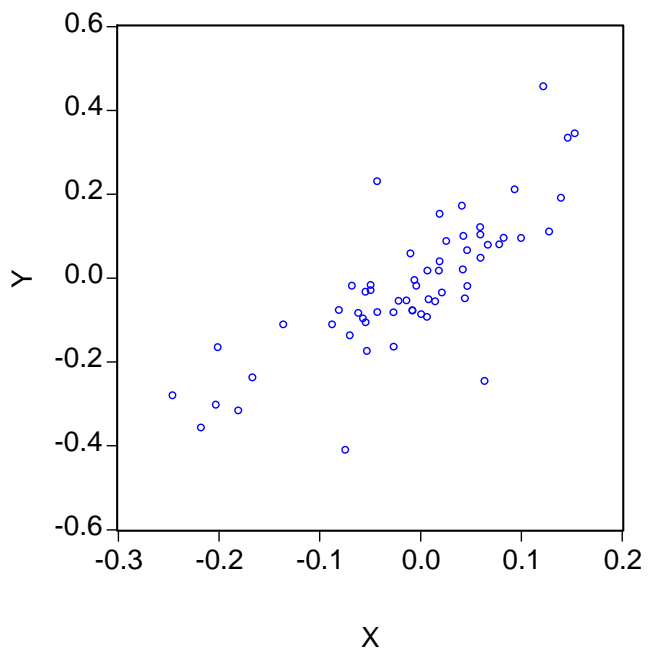

Figure 2 Scatter plot

In Figure 1, Shanghai composite index yield is named $X$ (market yields), China Citic Bank stock yields is named $Y$, and $Y$ and $X$ trend diagrams are got. The figure shows: (1) X and $Y$ shape (2) $Y$ changes as $\mathrm{X}$ volatility.

It can be seen from Figure 2 that $\mathrm{X}$ - market yields (\%) and Y -China Citic Bank stock returns (\%) are closely related. The following economic model can be established: $Y i=\beta 0+\beta 1 X+\mu i$ 。 .

Estimated parameters

\begin{tabular}{|c|c|c|c|c|}
\hline \multicolumn{5}{|c|}{$\begin{array}{l}\text { Dependent Variable: } Y \\
\text { Method: Least Squares } \\
\text { Date: } 06 / 02 / 13 \text { Time: } 21: 32 \\
\text { Sample: } 2008: 01 \text { 2012:12 } \\
\text { Included observations: } 60\end{array}$} \\
\hline Variable & Coefficient & Std. Error & $\mathrm{t}$-Statistic & Prob. \\
\hline C & -0.003213 & 0.013195 & -0.243505 & 0.8085 \\
\hline$x$ & 1.451148 & 0.146715 & 9.890916 & 0.0000 \\
\hline R-squared & 0.627800 & \multicolumn{2}{|c|}{ Mean dependent var } & -0.017243 \\
\hline Adjusted R-squared & 0.621383 & \multicolumn{2}{|c|}{ S.D. dependent var } & 0.165148 \\
\hline S.E. of regression & 0.101619 & \multicolumn{2}{|c|}{ Akaike info criterion } & -1.702410 \\
\hline Sum squared resid & 0.598931 & \multicolumn{2}{|c|}{ Schwarz criterion } & -1.632598 \\
\hline Log likelihood & 53.07230 & \multicolumn{2}{|l|}{ F-statistic } & 97.83023 \\
\hline Durbin-Watson stat & 2.140225 & \multicolumn{2}{|c|}{ Prob(F-statistic) } & 0.000000 \\
\hline
\end{tabular}

Figure 3 OLS regression figure

\begin{tabular}{|c|c|c|c|c|}
\hline $\begin{array}{l}\text { F-statistic } \\
\text { Obs }^{\star} R \text {-squared }\end{array}$ & $\begin{array}{l}0.356660 \\
0.741582\end{array}$ & $\begin{array}{l}\text { Probability } \\
\text { Probability }\end{array}$ & & $\begin{array}{l}0.701562 \\
0.690188\end{array}$ \\
\hline \multicolumn{5}{|c|}{$\begin{array}{l}\text { Test Equation: } \\
\text { Dependent Variable: RESID } 2 \\
\text { Method: Least Squares } \\
\text { Date: 06/04/13 Time: } 15: 38 \\
\text { Sample: } 2008: 01 \text { 2012:12 } \\
\text { Included observations: } 60\end{array}$} \\
\hline Variable & Coefficient & Std. Error & $\mathrm{t}$-Statistic & Prob. \\
\hline $\begin{array}{c}C \\
X \\
X^{n} 2\end{array}$ & $\begin{array}{l}0.009389 \\
0.033027 \\
0.112815\end{array}$ & $\begin{array}{l}0.003605 \\
0.039124 \\
0.270628\end{array}$ & $\begin{array}{l}2.604502 \\
0.844168 \\
0.416864\end{array}$ & $\begin{array}{l}0.0117 \\
0.4021 \\
0.6783\end{array}$ \\
\hline $\begin{array}{l}\text { R-squared } \\
\text { Adjusted R-squared } \\
\text { S.E. of regression } \\
\text { Sum squared resid } \\
\text { Log likelihood } \\
\text { Durbin-Watson stat }\end{array}$ & $\begin{array}{r}0.012360 \\
-0.022294 \\
0.023137 \\
0.030513 \\
142.3817 \\
1.931999\end{array}$ & \multicolumn{2}{|c|}{$\begin{array}{l}\text { Mean dependent var } \\
\text { S.D. dependent var } \\
\text { Akaike info criterion } \\
\text { Schwarz criterion } \\
\text { F-statistic } \\
\text { Prob(F-statistic) }\end{array}$} & $\begin{array}{r}0.009982 \\
0.022883 \\
-4.646057 \\
-4.541340 \\
0.356660 \\
0.701562\end{array}$ \\
\hline
\end{tabular}

Figure 4 Heteroscedasticity testing

The regression equation is obtained by data in Figure 3:

$\mathrm{Y}=-0.003213+1.451148 \mathrm{X}$

$$
(-0.243505) \quad(9.890916)
$$

The overall parameters: $\mathrm{R} 2=0.627800, \overline{\mathbf{R}^{\mathbf{2}}}=0.621383, \mathrm{~F}=97.83023$, significance level: $a=$ $5 \%, \mathrm{t} 0.05(58)=1.671, \mathrm{~F} 0.05(1,58)=4.00$

C. Model test

1) Economic significance test

$\beta 1$ estimate value is 1.451148 , which indicates that when the market yields has $1 \%$ increase, China Citic Bank stock yield increases by $1.451148 \%$, and makes economic sense.

2) Fit goodness test

In this case, $\mathrm{R} 2=0.627800$. The model on the whole has a better sample data fitting degree. The explanatory variables "Shanghai composite index yield" has explained the vast majority of differences of explained variables "stock monthly yield".

3) Heteroscedasticity test and eliminate 
First of all, do white test on regression equation, and it is concluded that $\mathrm{P}$ value is greater than 0.05 , so there is no heteroscedasticity.

4)Autocorrelation test and eliminate

According to OLS regression data, $\mathrm{D}-\mathrm{W}=2.140225$, because: $\mathrm{n}=60, \mathrm{k}=1$, take a significant level alpha $=0.05$, look up table $\mathrm{dl}=1.549$, $\mathrm{du}=1.616,4-\mathrm{du}=2.384>\mathrm{D}-\mathrm{W}>\mathrm{du}=1.616$, so there is no correlation. Use partial autocorrelation coefficient method to test autocorrelation. Use Eviews software, and the results are in the following table. It can be seen that all $|\mathrm{PAC}|<0.5$, as a result, there is no autocorrelation.

\begin{tabular}{|c|c|c|c|c|c|}
\hline Autocorrelation & Partial Correlation & $A C$ & PAC & Q-Stat & Prob \\
\hline 151 & 151 & $1-0.083$ & -0.083 & 0.4389 & 0.508 \\
\hline 1 1 & & 20.046 & 0.039 & 0.5726 & 0.751 \\
\hline $1 \sqrt{1}$ & 11 & 30.045 & 0.052 & 0.7029 & 0.873 \\
\hline 15 & 10 & $4-0.075$ & -0.070 & 1.0750 & 0.898 \\
\hline : & : & $5-0.209$ & -0.229 & 4.0349 & 0.544 \\
\hline 171 & 17 & $6-0.013$ & -0.050 & 4.0467 & 0.670 \\
\hline \begin{tabular}{l|l}
1 & 1
\end{tabular} & 111 & $7-0.006$ & 0.020 & 4.0493 & 0.774 \\
\hline 10 & 101 & $8-0.082$ & -0.066 & 4.5274 & 0.807 \\
\hline 11 & 1 & $9-0.007$ & -0.059 & 4.5309 & 0.873 \\
\hline 1 ا 1 & 1 & $10 \quad 0.203$ & 0.163 & 7.5907 & 0.669 \\
\hline 151 & $1 \sqrt{1}$ & $11-0.058$ & -0.025 & 7.8445 & 0.727 \\
\hline 111 & 11 & $\begin{array}{ll}12 & 0.027\end{array}$ & -0.015 & 7.8992 & 0.793 \\
\hline 11 & 101 & $13-0.011$ & -0.062 & 7.9081 & 0.850 \\
\hline $1 \mathrm{~b}$ & 101 & 140.043 & 0.066 & 8.0607 & 0.886 \\
\hline 151 & 151 & $\begin{array}{ll}15 & 0.045\end{array}$ & 0.140 & 8.2300 & 0.914 \\
\hline 11 & & $\begin{array}{ll}16 & 0.077\end{array}$ & 0.084 & 8.7250 & 0.924 \\
\hline $1[1$ & $1 \sqrt{1}$ & $17-0.004$ & -0.020 & 8.7268 & 0.948 \\
\hline 101 & 10 & $18-0.052$ & -0.052 & 8.9658 & 0.961 \\
\hline 1 1 & 1 & $\begin{array}{ll}19 & 0.088\end{array}$ & 0.131 & 9.6751 & 0.961 \\
\hline 吅 1 & 回 & $20-0.218$ & -0.202 & 14.094 & 0.826 \\
\hline 1 1 & , & $21-0.136$ & -0.179 & 15.870 & 0.777 \\
\hline 1 & 田 & $22-0.169$ & -0.226 & 18.653 & 0.667 \\
\hline 11 & & $23-0.014$ & 0.022 & 18.674 & 0.720 \\
\hline 10 & & $24-0.067$ & -0.056 & 19.139 & 0.745 \\
\hline $1 b_{1}$ & & 250.137 & -0.005 & 21.122 & 0.686 \\
\hline 1曰 & ' • & $\begin{array}{ll}26 & 0.277\end{array}$ & 0.222 & 29.498 & 0.289 \\
\hline 101 & 1 & $27-0.164$ & -0.193 & 32.521 & 0.213 \\
\hline 101 & 171 & \begin{tabular}{|ll}
28 & 0.096
\end{tabular} & 0.017 & 33.594 & 0.215 \\
\hline
\end{tabular}

5)Unit root test

Figure 5 autocorrelation test figure

Given that possible spurious regression may appear in the set of time series, data $\mathrm{Y}$ and $\mathrm{X}$ are made unit root test respectively. First of all, do unit root test on $\mathrm{X}$, and the results are as follows:

\begin{tabular}{|c|c|c|c|}
\hline ADF Test Statistic & -7.882364 & $\begin{array}{ll}1 \% & \text { Critical Value } \\
5 \% & \text { Critical Value } \\
10 \% & \text { Critical Value }\end{array}$ & $\begin{array}{l}-2.6019 \\
-1.9460 \\
-1.6187\end{array}$ \\
\hline \multicolumn{4}{|c|}{${ }^{*}$ MacKinnon critical values for rejection of hypothesis of a unit root. } \\
\hline \multicolumn{4}{|c|}{$\begin{array}{l}\text { Augmented Dickey-Fuller Test Equation } \\
\text { Dependent Variable: } D(X) \\
\text { Method: Least Squares } \\
\text { Date: 06/04/13 Time: } 16: 08 \\
\text { Sample(adjusted): } 2008: 022012: 12 \\
\text { Included observations: } 59 \text { after adjusting endpoints }\end{array}$} \\
\hline Variable & Coefficient & $\mathrm{t}$-Statistic & Prob. \\
\hline$X(-1)$ & -1.027297 & $0.130329 \quad-7.882364$ & 0.0000 \\
\hline $\begin{array}{l}\text { R-squared } \\
\text { Adjusted R-squared } \\
\text { S.E. of regression } \\
\text { Sum squared resid } \\
\text { Log likelihood }\end{array}$ & $\begin{array}{l}0.516349 \\
0.516349 \\
0.088779 \\
0.457139 \\
59.66165\end{array}$ & $\begin{array}{l}\text { Mean dependent var } \\
\text { S.D. dependent var } \\
\text { Akaike info criterion } \\
\text { Schwarz criterion } \\
\text { Durbin-Watson stat }\end{array}$ & $\begin{array}{r}0.005303 \\
0.127657 \\
-1.988531 \\
-1.953318 \\
1.954515\end{array}$ \\
\hline
\end{tabular}

Figure 6 Unit root test of the $\mathrm{X}$ chart

\begin{tabular}{llll} 
ADF Test Statistic & -8.325110 & $1 \%$ Critical Value & -2.6019 \\
& & $5 \%$ Critical Value & -1.9460 \\
& $10 \%$ Critical Value & -1.6187 \\
\hline
\end{tabular}

*MacKinnon critical values for rejection of hypothesis of a unit root.

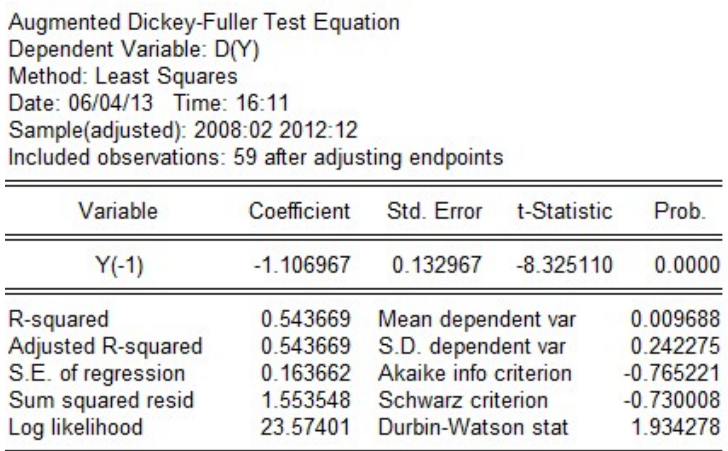

Figure 7 Unit root test chart of $Y$

By Test results, it can be seen that X's ADF Test Statistic $=-7.882364$, which is less than-2.574553 when confidence level is $1 \%$, so $\mathrm{X}$ unit root test is passed. Then unit root test is done on $\mathrm{Y}$, and the results are as follows:

By the test results, you can see that Y's ADF Test Statistic $=-8.325110$, which is less than-2.6019 when confidence level is $1 \%$, so Y's unit root test is ok. So we can conclude that they are all smooth sequences, and there is no spurious regression.

\section{Conclusion}

By the above economics tests, the final model is got: 


$$
\begin{gathered}
Y=-0.003213+1.451148 X \\
(-0.243505) \quad(9.890916)
\end{gathered}
$$

The overall parameters: $\mathrm{R} 2=0.627800, \overline{\mathrm{R}^{\mathbf{2}}}=0.621383, \mathrm{~F}=97.83023$, significance level: $\alpha=$ $5 \%, \mathrm{t} 0.05(58)=1.671, \mathrm{~F} 0.05(1,58)=4.00$

First, the model's determination coefficient is R2 $=0.627800$, which indicates that among the influence factors of China Citic Bank shares yield (Y), 62.78\% can be explained by estimated model. When the significance level alpha $=5 \%$, F test's theoretical value is 4.00 , model of F's test value is 97.83023, F > F0.05, and model's linear relationship is significant. When significance level alpha $=$ $5 \%$, the theoretical value of $\mathrm{t}$ test is 1.671 . Variable $\mathrm{X}$ 's $\mathrm{t}$ test value is 9.890916, $\mathrm{X}$ can stand test. Explanatory variable $\mathrm{X}$ - of Shanghai stock market yields have significant influence on Y-China Citic Bank stock yield.

Second, in determining the final model, we can see that Shanghai market yields rose per one percent, China Citic Bank yield rose $1.451148 \%$, that is to say, Shanghai index has significant influence on the stock of China Citic Bank.

\section{References}

[1] Zhang Wen, Jin Junhui, Liu Jiangjiang. An empirical study of Shanghai CAPM model [J]. Journal of Fujian Business College, 2008 (4).

[2] Chen Langnan, Qu WenZhou. An empirical study on capital asset pricing model [J]. Journal of Economic Research. 2000 (4).

[3] Li Shijuan. On beta coefficient calculation in CAPM, [J] Market Weekly. 2004 (5).

[4] Liang Guokai. Review on beta coefficient empirical research and China's stock market [J] China's Collective Economy, 2009 (2).

[5] Li Yunyi. Outlook on Chinese stock market beta coefficient study [J]. Journal of Information Science and Technology, 2008 (26).

[6] Guo Feng, Zhao Minan. The empirical study based on CAPM model---- China's capital market efficiency comparison and analysis before and after Equity division reform, [J]. Journal of Quantitative Technical Economics, 2008 (5).

[7] Ding Zhiguo, Su Zhi, Du Xiaoyu. CAPM inter-temporal paradox: beta coefficient time-varying existence theory study [J]. Journal of Jilin University Journal of Social Science, 2008 (1). 